\title{
Treatability of South African surface waters by activated carbon
}

\author{
KP Lobanga, J Haarhoff* and SJ van Staden \\ Department of Civil Engineering Science, University of Johannesburg, PO Box 524, Auckland Park, 2006, South Africa
}

\begin{abstract}
Natural organic matter (NOM) in water resources for drinking purposes can be removed by different methods, including activated carbon adsorption. Due to the variability of NOM in natural waters, both in terms of its nature and its concentration, a study was undertaken to investigate NOM removal for a wide range of South African surface waters, sampled at different periods, by the use of granular activated carbon (GAC). NOM removal was assessed by measuring the ultraviolet (UV) absorbance at 3 wavelengths, namely, $254 \mathrm{~nm}\left(\mathrm{UV}_{254}\right), 272 \mathrm{~nm}\left(\mathrm{UV}_{272}\right)$ and $300 \mathrm{~nm}\left(\mathrm{UV}_{300}\right)$. A comparison of data between the three wavelengths showed that any of the three wavelengths can be used to assess NOM removal by GAC, which is well described by the Freundlich equilibrium equation. A treatment target of $40 \%$ removal of initial $\mathrm{UV}_{254}$ absorbance was considered. It was observed that, although the GAC dosage was generally a function of the initial $\mathrm{UV}_{254}$ absorbance, differences existed between waters. This suggests that GAC usage rate is not only a function of the initial UV absorbance but also of the NOM composition, indicating a need for improved NOM characterisation. Comparison between the UV absorbance and dissolved organic carbon (DOC) data suggested that for some waters $\mathrm{UV}_{254}$ absorbance can be used as a rapid substitute for DOC. Finally, the high GAC dosage rates required for the target criterion revealed that the process is inadequate for use at the initial stage of raw water treatment; GAC adsorption should be used at later stages of drinking water treatment.

Keywords: activated carbon, adsorption, Freundlich isotherm, natural organic matter, surface water, ultraviolet absorbance
\end{abstract}

\section{INTRODUCTION}

Natural organic matter is a complex mixture of organic compounds such as humic and fulvic acids, proteins, amino acids and carbohydrates, resulting from the degradation of plants, animals and microorganisms (Cornelissen et al., 2008; Edzwald and Tobiason, 2010; García et al., 2011). Based on its origin, NOM can be placed in two categories, namely autochthonous organic matter (formed within the water body) and allochthonous organic matter (produced elsewhere and transported to the water body) (Edzwald and Tobiason, 2010). It can be further classified as either particulate organic matter (POM) or dissolved organic matter (DOM). NOM in water affects the organoleptic aspects of the drinking water, promotes bacterial regrowth in drinking water distribution systems and reacts with disinfectants and oxidants, producing disinfection by-products and other products (Van der Kooij, 1998; Batterman et al., 2000; Hallam et al., 2001; Melnick et al., 2007; Edzwald and Tobiason, 2010; Ødegaard et al., 2010). NOM in raw water can be removed by different methods including the use of activated carbon. Adsorption of DOM by the activated carbon is a function of the NOM composition (nature and concentration), $\mathrm{pH}$ of the water, water temperature, molecular size and concentrations of some ions, such as magnesium and calcium (Schreiber et al., 2005).

In drinking water treatment plants, adsorption by activated carbon is a well-established process. The activated carbon is used either as powder (powdered activated carbon - PAC) or as granules (granular activated carbon - GAC). The PAC is generally used at the beginning of the treatment process (at or just

This paper was originally presented at the 2012 Water Institute of Southern Africa (WISA) Biennial Conference, Cape Town, 6-10 May 2012.

* To whom all correspondence should be addressed.

푱 +27 11559 2148; e-mail: jhaarhoff@uj.ac.za after coagulation), while the GAC is used at a later stage of the treatment (generally before disinfection) (Kristiana et al. 2011; Matilainen et al., 2006). PAC is added to the water as slurry, while the GAC is placed in filter beds.

The aim of this study was to investigate NOM removal for a large range of South African surface waters by the use of GAC. The removal was assessed by measuring the UV absorbance at $254 \mathrm{~nm}\left(\mathrm{UV}_{254}\right), 272 \mathrm{~nm}\left(\mathrm{UV}_{272}\right)$ and $300 \mathrm{~nm}\left(\mathrm{UV}_{300}\right)$. For some waters, the DOC values were used and compared with the UV absorbance values.

\section{MATERIALS AND METHODS}

\section{Source water}

Eight surface waters were sampled. As shown in Fig. 1, the sampling sites were chosen from different geographic regions in South Africa in order to include differences in NOM composition. The surface waters were also chosen to account for the main surface water types of South Africa (Oberholster, 2010). The different categories of waters are summarised in Table 1 . The raw waters were collected at 5 different times to capture the seasonal variations in NOM composition (Sharp et al., 2006; Uyak et al., 2008). The sampling was done during the following periods: Round 1 from February to April 2010; Rounds 2, 3 and 4 in July 2010, November 2010 and February 2011, respectively. Round 5 waters were sampled in May and June 2011. Raw waters were collected (using two $25 \ell$ plastic containers) and stored at approximately $4^{\circ} \mathrm{C}$, in the dark. Analysis of the samples was done within 2 months, during which there was no significant change in NOM concentration or composition (Haarhoff et al., 2013).

\section{Granular activated carbon preparation}

The activated carbon used was a product commercially available in South Africa and kindly provided by a local supplier. 


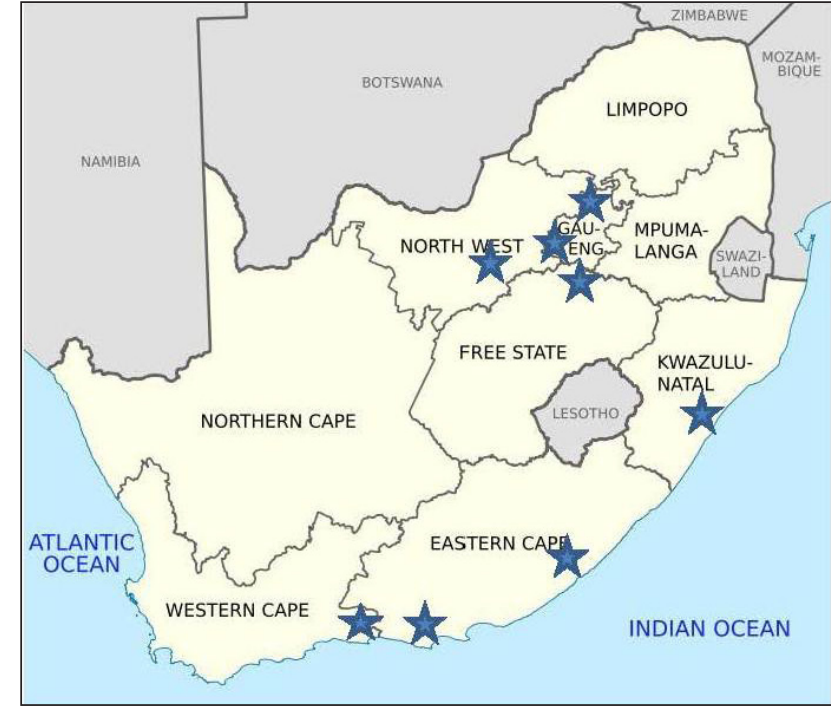

Figure 1

Sampling sites

It is a bituminous, coal-based GAC used in liquid phase applications to remove organic compounds. Figure 2 shows the GAC as supplied (a) and after grinding (b).

The general practice adopted for activated carbon studies is to grind the virgin GAC and use a fraction of the finely ground GAC. The main advantages of using the fine GAC are that it requires a shorter time to reach equilibrium with a smaller chance of biological interference. The unground GAC requires a longer time to reach equilibrium, which allows biological activity to take place and interfere significantly with the adsorption process (Randtke and Snoeyink, 1983). These authors found that the adsorptive capacity of the activated carbon was not significantly affected by grinding to a smaller size. When GAC is used in a column test, it is washed prior to use in order to remove the fine particles that can contaminate the effluent or plug the underdrain system. However, if the GAC is used in a batch equilibrium test, it is not necessary to apply this rinsing step since the fine particles are a very small fraction of the total mass of the carbon used.

To obtain the powdered activated carbon, $100 \mathrm{~g}$ of virgin GAC was crushed with a porcelain mortar and pestle. Using a vibratory sieve shaker, the fraction passing the $300 \mu \mathrm{m}$ sieve was collected and stored in a glass container. The procedure was repeated until the quantity of fine GAC obtained was sufficient for further testing. (a)

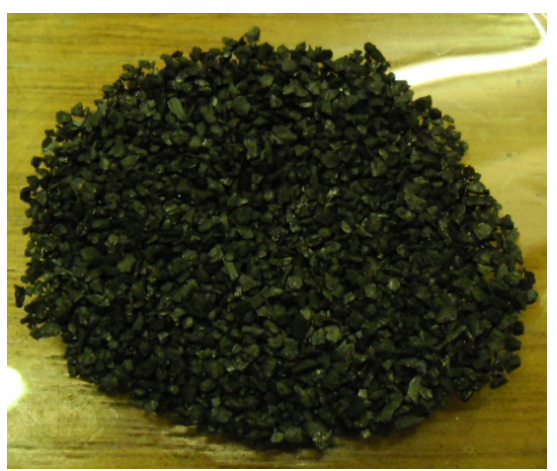

(b)

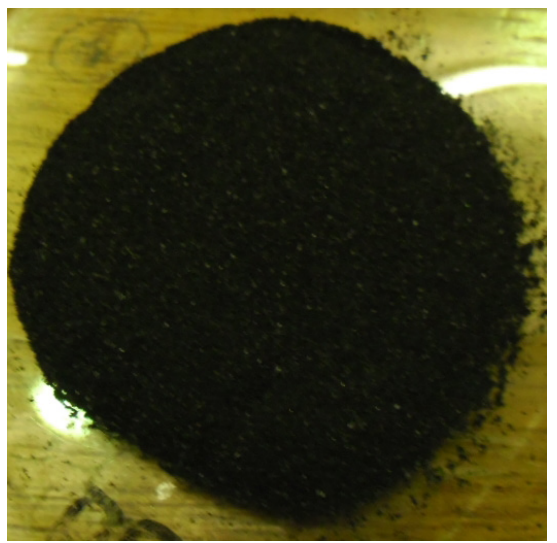

\section{Batch adsorption tests}

Batch tests were conducted at room temperature $\left(20-25^{\circ} \mathrm{C}\right)$. On the day of testing, at least $3 \ell$ of raw water was removed from refrigeration and stirred in the laboratory at $300 \mathrm{r} \cdot \mathrm{min}^{-1}$ for a minimum of $30 \mathrm{~min}$. Different masses of carbon (blank, $6.25,8.25,12.50,16.50,25.00,33.25$ and $50.00 \mathrm{mg}$ ) were each added to $250 \mathrm{~m} \ell$ of raw water in $500 \mathrm{~m} \ell$ Erlenmeyer flasks. The samples were placed on an orbital shaker table at $140 \mathrm{r} \cdot \mathrm{min}^{-1}$ for $72 \mathrm{~h}$ (3 days). The rotation speed of $140 \mathrm{r} \cdot \mathrm{min}^{-1}$ was chosen as it was visually observed to provide good mixing. After 3 days, the samples were filtered through a $0.45 \mu \mathrm{m}$ hydrophilic Durapore (PVDF) membrane filter (Millipore Millex-HV) before the ultraviolet absorbance was measured at $254 \mathrm{~nm}$ $\left(\mathrm{UV}_{254}\right), 272 \mathrm{~nm}\left(\mathrm{UV}_{272}\right)$ and $300 \mathrm{~nm}\left(\mathrm{UV}_{300}\right)$ using a spectrophotometer (Ultrospec II UV/Vis). The DOC values of some samples were also measured using a total organic carbon analyser (Teledyne Tekmar, TOC fusion).

\begin{tabular}{|l|l|}
\hline \multicolumn{2}{|c|}{ TABLE 1 } \\
Surface water categories \\
\hline Plant names & Categories \\
\hline Loerie (Water Treatment Plant) & Low-alkalinity low-colour water \\
\hline Olifantsvlei (Wastewater Treatment Plant) & Sewage effluent \\
\hline Plettenberg Bay (Water Treatment Plant) & Very soft, highly coloured water \\
\hline Rietvlei (Water Treatment Plant) & Eutrophic reservoir water \\
\hline Stilfontein (Water Treatment Plant) & Eutrophic river water \\
\hline Umzoniana (Water Treatment Plant) & Moderate-alkalinity low-colour \\
\hline Vereeniging (Water Treatment Plant) & Oligotrophic reservoir water \\
\hline Wiggins (Water Treatment Plant) & Low-alkalinity reservoir water \\
\hline
\end{tabular}

*The Olifantsvlei Wastewater Treatment Plant is not a direct drinking water source, but discharges into the Klip River and is therefore a worst-case indicator for rivers and streams which receive large volumes of treated sewage effluents. 
The Freundlich equation was used for modelling the $\mathrm{UV}_{254}$ absorbance and shown in Eq. (1):

$$
q_{e}=K C_{e}^{n}
$$

where:

$q_{e}=$ equilibrium NOM concentration in the solid phase

$\left(\ell \cdot \mathrm{mg}^{-1} \cdot \mathrm{m}^{-1}\right)$

$C_{e}=$ equilibrium NOM concentration in water $\left(\mathrm{m}^{-1}\right)$

$K$ and $n=$ Freundlich constant and exponent, respectively.

The Freundlich parameters $K$ and $n$ were determined from the results of absorbance at the three wavelengths. The parameters $K$ and $n$ are related to the capacity and affinity of the carbon for NOM molecules, respectively (Cornelissen et al., 2008).

\section{Performance indicator}

The required GAC dosage for each raw water was determined for an arbitrary treatment goal of $40 \%$ removal of initial $\mathrm{UV}_{254}$ absorbance.

The GAC dosage calculation was derived from Eq. (1) as follows:

$$
\begin{aligned}
& \frac{C_{i}-C_{e}}{M}=K C_{e}^{n} \\
& M=\frac{C_{i}-C_{e}}{K C_{e}^{n}}
\end{aligned}
$$

If $C_{i}$ is removed by $40 \%$

$$
M=\frac{C_{i}-0.60 C_{i}}{K\left(0.60 C_{i}\right)^{n}}
$$

where:

$$
\begin{aligned}
& C_{i}=\text { initial NOM concentration in raw water }\left(\mathrm{m}^{-1}\right) \\
& M=\text { GAC dosage }\left(\mathrm{mg} \cdot \ell^{-1}\right)
\end{aligned}
$$

\section{RESULTS AND DISCUSSION}

\section{Comparison of absorbance results at three wavelengths}

The indicators used and reported in this paper are the $\mathrm{UV}_{254}$ absorbance (indicative of the presence of conjugated $\mathrm{C}=\mathrm{C}$ double bonds or compounds with aromatic structure) (Edzwald and Tobiason, 2010), $\mathrm{UV}_{272}$ absorbance (reported by some as the best indicator of total organic halogen and trihalomethane formation (Korshin et al., 1997)) and $\mathrm{UV}_{300}$ absorbance (used by some South African water treatment plants as an operational parameter) (Haarhoff et al., 2012). Ultraviolet absorbance at $254 \mathrm{~nm}\left(\mathrm{UV}_{254}\right)$ is used by many organisations to characterise NOM (Karanfil et al., 2002). It was found that, when plotting the graphs of equilibrium UV absorbance in water $\left(C_{e}\right)$ versus the GAC dosage, the removal patterns were the same for all wavelengths, as shown in Figs. 3 and 4 (Round 5 Stilfontein and Round 3 Umzoniana waters, respectively).

Table 2 gives the ratios between $\mathrm{UV}_{272}$ and $\mathrm{UV}_{254}$ and, $\mathrm{UV}_{300}$ and $\mathrm{UV}_{254}$ for the above-mentioned waters. It demonstrates that the ratios between $U_{272}$ and $U_{254}$ were practically the same for all the GAC dosages for these two water samples. The same conclusion applied to the ratios between the $U_{300}$ and $\mathrm{UV}_{254}$. The average value, for all the water samples, of the ratio between $\mathrm{UV}_{272}$ and $\mathrm{UV}_{254}$ was $0.82(\mathrm{SD}=0.0006)$, and for the ratio between $\mathrm{UV}_{300}$ and $\mathrm{UV}_{254}$ was $0.53(\mathrm{SD}=0.0033)$.

Table 3 presents the UV absorbance removal at different wavelengths for certain waters. UV absorbance removal was

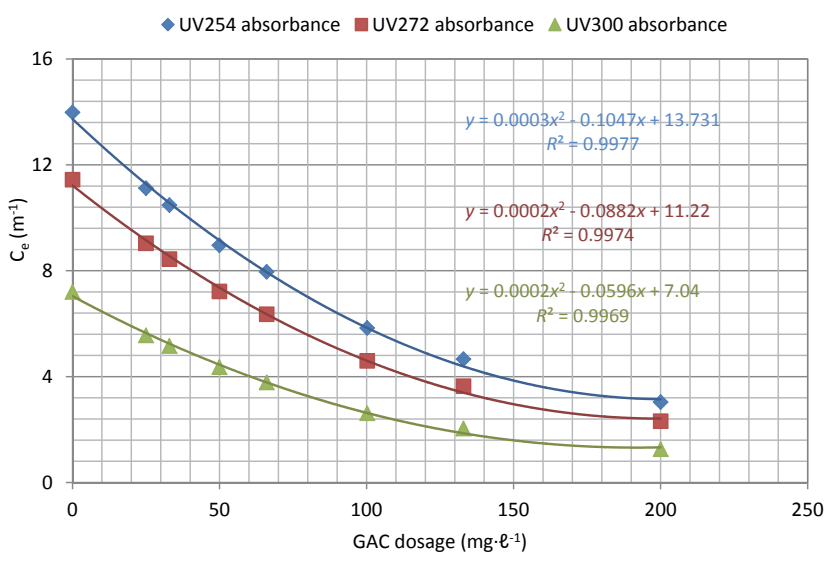

Figure 3

Equilibrium UV absorbance vs. GAC dosage

\begin{tabular}{|c|c|c|c|c|}
\hline \multicolumn{5}{|c|}{$\begin{array}{l}\text { TABLE } 2 \\
\text { Ratios between } \mathrm{UV}_{272} \text { and UV } \mathrm{V}_{254} \text { and, } \mathrm{UV}_{300} \text { and UV } \\
\text { absorbance results }\end{array}$} \\
\hline \multirow{2}{*}{$\begin{array}{l}\text { GAC dosage } \\
\left(\mathrm{mg} \cdot \ell^{-1}\right)\end{array}$} & \multicolumn{2}{|c|}{$\begin{array}{c}\text { Round } 5 \text { - } \\
\text { Stilfontein water }\end{array}$} & \multicolumn{2}{|c|}{$\begin{array}{c}\text { Round 3- } \\
\text { Umzoniana water }\end{array}$} \\
\hline & $\mathrm{UV}_{272} / \mathrm{UV}_{254}$ & $\mathrm{UV}_{300} / \mathrm{UV}_{254}$ & $\mathrm{UV}_{272} / \mathrm{UV}_{254}$ & $\mathrm{UV}_{300} / \mathrm{UV}_{254}$ \\
\hline 0 & 0.82 & 0.52 & 0.80 & 0.48 \\
\hline 25 & 0.81 & 0.50 & 0.81 & 0.48 \\
\hline 33 & 0.81 & 0.49 & 0.81 & 0.48 \\
\hline 50 & 0.81 & 0.49 & 0.81 & 0.48 \\
\hline 66 & 0.80 & 0.47 & 0.80 & 0.47 \\
\hline 100 & 0.79 & 0.45 & 0.81 & 0.47 \\
\hline 133 & 0.78 & 0.44 & 0.80 & 0.47 \\
\hline 200 & 0.76 & 0.41 & 0.79 & 0.48 \\
\hline
\end{tabular}
for the Round 5 Stilfontein water

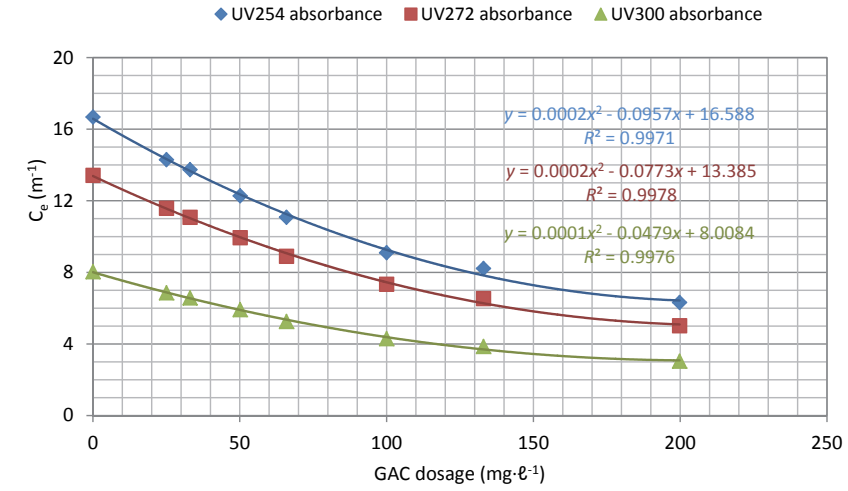

Figure 4

Equilibrium UV absorbance vs. GAC dosage for the Round 3 Umzoniana water

the same for a particular water at the same GAC dosage for the three wavelengths.

Table 4 compares the GAC dosages required to remove $40 \%$ of the initial UV absorbance at 3 wavelengths for 3 different waters. The dosages were calculated by applying the Freundlich equation.

Table 4 indicates that the dosage required to remove the initial UV absorbance by a fixed percentage (in this case 40\%) was approximately the same for all three wavelengths for each water sample. It also shows that the required dosage varied 


\begin{tabular}{|c|c|c|c|c|c|c|c|c|c|}
\hline & & & UV ab & $\begin{array}{l}\mathrm{TAB} \\
\text { orbane }\end{array}$ & $\begin{array}{l}\text { E } 3 \\
\text { remo }\end{array}$ & al (\%) & & & \\
\hline & & & & Initi & I remov & I (\%) & & & \\
\hline dosage & Rou & Id $1-\mathrm{Lc}$ & erie & Rou & d 2-Ri & tvlei & Round & 4-Olif & itsvlei \\
\hline & $\mathrm{UV}_{254}$ & $\mathrm{UV}_{272}$ & $u_{300}$ & $u_{254}$ & $u^{u V_{272}}$ & $u_{300}$ & $\mathrm{UV}_{254}$ & $u V_{272}$ & $u V_{300}$ \\
\hline 25 & 13 & 13 & 12 & - & - & - & - & - & - \\
\hline 33 & 17 & 17 & 17 & 23 & 24 & 24 & 25 & 26 & 25 \\
\hline 50 & 19 & 19 & 18 & 30 & 30 & 31 & 31 & 32 & 31 \\
\hline 66 & 26 & 27 & 26 & 39 & 40 & 40 & 40 & 40 & 39 \\
\hline 100 & 36 & 35 & 34 & 50 & 51 & 51 & 51 & 52 & 50 \\
\hline 133 & 44 & 43 & 41 & 60 & 60 & 60 & 57 & 58 & 55 \\
\hline 200 & 58 & 58 & 55 & 71 & 72 & 71 & 67 & 67 & 64 \\
\hline
\end{tabular}

\begin{tabular}{|l|c|c|c|}
\hline \multicolumn{4}{|c|}{$\begin{array}{c}\text { TABLE 4 } \\
\text { Dosages required to remove } \\
\text { 40\% of the initial UV absorbance }\end{array}$} \\
\hline $\begin{array}{l}\text { UV } \\
\text { absorbance }\end{array}$ & $\begin{array}{c}\text { Round 5 } \\
\text { Wiggins }\end{array}$ & $\begin{array}{c}\text { Round 5 } \\
\text { Olifantsvlei }\end{array}$ & $\begin{array}{c}\text { Round 2 } \\
\text { Plettenberg } \\
\text { Bay }\end{array}$ \\
\cline { 2 - 4 } & $\mathbf{M}\left(\mathrm{mg} \cdot \ell^{-1}\right)$ & $\mathrm{M}\left(\mathrm{mg} \cdot \boldsymbol{\ell}^{-1}\right)$ & $\mathrm{M}\left(\mathrm{mg} \cdot \boldsymbol{\ell}^{-1}\right)$ \\
\hline $\mathrm{UV}_{254}$ & 30 & 58 & 189 \\
\hline $\mathrm{UV}_{272}$ & 28 & 54 & 194 \\
\hline $\mathrm{UV}_{300}$ & 26 & 50 & 212 \\
\hline Average & 28 & 55 & 198 \\
\hline
\end{tabular}

TABLE 5

Freundlich parameters derived from $\mathrm{UV}_{254}$ absorbance data ${ }^{\ddagger}$

\begin{tabular}{|l|c|c|c|c|c|c|c|c|c|c|}
\hline \multirow{2}{*}{ Plant name } & \multicolumn{2}{|c|}{ Round 1 } & \multicolumn{2}{c|}{ Round 2 } & \multicolumn{2}{c|}{ Round 3 } & \multicolumn{2}{c|}{ Round 4 } & \multicolumn{2}{c|}{ Round 5 } \\
\cline { 2 - 12 } & $\mathbf{K}$ & $\mathbf{N}$ & $\mathbf{K}$ & $\mathbf{n}$ & $\mathbf{K}$ & $\mathbf{n}$ & $\mathbf{K}$ & $\mathbf{n}$ & $\mathrm{K}$ & $\mathbf{n}$ \\
\hline Umzoniana & $1.2 \mathrm{E}-2$ & 0.86 & $1.9 \mathrm{E}-2$ & 0.64 & $1.5 \mathrm{E}-2$ & 0.71 & $9.4 \mathrm{E}-3$ & 0.88 & $2.3 \mathrm{E}-3$ & 1.38 \\
\hline Wiggins & $1.4 \mathrm{E}-2$ & 1.03 & $2.2 \mathrm{E}-2$ & 0.95 & $1.2 \mathrm{E}-2$ & 1.22 & $5.0 \mathrm{E}-3$ & 1.61 & $4.1 \mathrm{E}-2$ & 0.43 \\
\hline Loerie & $1.2 \mathrm{E}-2$ & 0.75 & $1.2 \mathrm{E}-2$ & 0.88 & $1.0 \mathrm{E}-2$ & 0.83 & $1.5 \mathrm{E}-2$ & 0.71 & $3.5 \mathrm{E}-2$ & 0.32 \\
\hline Rietvlei & $2.8 \mathrm{E}-2$ & 0.51 & $2.2 \mathrm{E}-2$ & 0.63 & - & - & $2.2 \mathrm{E}-2$ & 0.57 & - & - \\
\hline Vereeniging & $3.4 \mathrm{E}-2$ & 0.41 & - & - & $1.5 \mathrm{E}-2$ & 1.71 & - & - & $1.2 \mathrm{E}-2$ & 0.85 \\
\hline Olifantsvlei & $2.5 \mathrm{E}-2$ & 0.73 & $1.8 \mathrm{E}-2$ & 0.79 & $1.6 \mathrm{E}-2$ & 0.78 & $1.1 \mathrm{E}-2$ & 0.97 & $2.4 \mathrm{E}-2$ & 0.65 \\
\hline Stilfontein & $2.8 \mathrm{E}-2$ & 0.58 & $1.5 \mathrm{E}-2$ & 0.80 & $1.4 \mathrm{E}-2$ & 0.82 & $3.4 \mathrm{E}-2$ & 0.46 & $3.0 \mathrm{E}-2$ & 0.55 \\
\hline Plettenberg Bay & - & - & $7.2 \mathrm{E}-3$ & 0.75 & - & - & - & - & $2.4 \mathrm{E}-5$ & 2.23 \\
\hline
\end{tabular}

${ }^{*}$ Cells with no data had $R^{2}$ values that were very poor $\left(R^{2} \leq 0.11\right)$ or there was no data. The non-shaded cells represent those samples where the $R^{2}$ values were very good ( $R^{2}$ range 0.91-1.00). The shaded cells were those samples where $R^{2}$ was less than 0.90 .

\begin{tabular}{|c|c|c|c|c|c|c|c|c|c|c|}
\hline \multicolumn{11}{|c|}{$\begin{array}{c}\text { TABLE } 6 \\
\text { GAC dosage } M\left(\mathrm{mg} \cdot \ell^{-1}\right) \text { for removal of } 40 \% \text { of } \mathrm{UV}_{254} \text { absorbance }\end{array}$} \\
\hline \multirow[t]{2}{*}{ Plant name } & \multicolumn{2}{|c|}{ Round 1} & \multicolumn{2}{|c|}{ Round 2} & \multicolumn{2}{|c|}{ Round 3} & \multicolumn{2}{|c|}{ Round 4} & \multicolumn{2}{|c|}{ Round 5} \\
\hline & $C_{i}$ & $M$ & $C_{i}$ & $M$ & $C_{i}$ & $M$ & $C_{i}$ & $M$ & $C_{i}$ & $M$ \\
\hline Umzoniana & 15.8 & 78 & 14.8 & 75 & 16.7 & 89 & 19 & 96 & 28.2 & - \\
\hline Wiggins & 7.0 & 46 & 6.3 & 33 & 6.1 & 42 & 7.6 & 53 & 4.9 & 30 \\
\hline Loerie & 25.2 & - & 17.3 & 71 & 6.7 & 82 & 15.1 & 83 & 13.3 & 79 \\
\hline Rietvlei & 18.4 & 79 & 17.2 & 70 & 19.2 & - & 24.0 & 94 & 19.7 & - \\
\hline Olifantsvlei & 13.1 & 48 & 16.4 & 61 & 15.8 & 68 & 15.4 & 67 & 14.3 & 58 \\
\hline Stilfontein & 16.4 & 63 & 15.3 & 68 & 18.5 & 72 & 33.7 & - & 14.0 & 58 \\
\hline Plettenberg Bay & - & - & 30.4 & 189 & 43.8 & - & 62.9 & - & 49.3 & - \\
\hline
\end{tabular}

with the water type. To remove $40 \%$ of initial UV absorbance, Round 5 Olifantsvlei water required almost twice the dosage of the Wiggins Round 5 water, whilst the Plettenberg Bay Round 2 needed approximately 7 times more GAC than the Round 5 Wiggins water. These differences of dosages show that NOM composition varies with water source. Thus, improved NOM characterisation is required.

\section{$U_{254}$ absorbance values}

Based on all the findings presented above, it appeared that any of the three wavelengths investigated could be used to assess NOM removal. In this paper, the rest of the data analysis was done with the $\mathrm{UV}_{254}$ absorbance value, as this is the most popular wavelength used in the published literature (Karanfil et al., 2002). The Freundlich equilibrium equation was then applied to $\mathrm{UV}_{254}$ absorbance data. Table 5 presents the Freundlich parameters of the water samples. Round 1 Loerie and Vereeniging had an $R^{2}$ of 0.80 and 0.73 , respectively, while Round 3 of the Vereeniging water had an $R^{2}$ of 0.78 . The lowest $R^{2}, 0.61$, for Round 4 was found for the Stilfontein water. For Round 5, the Umzoniana, Vereeniging and Plettenberg Bay waters displayed $R^{2}$ values of $0.78,0.83$ and 0.66 , respectively.

\section{Performance criterion}

The required GAC dosage was calculated, i.e. the carbon dosage required to remove the initial $\mathrm{UV}_{254}$ absorbance $\left(C_{i}\right)$ by $40 \%$. Table 6 represents the calculated GAC dosage $M\left(\mathrm{mg} \cdot \ell^{-1}\right)$ to meet the required criterion.

In general, the smaller the initial $\mathrm{UV}_{254}$ absorbance, the smaller the required GAC dosage, e.g. all of the Wiggins water samples. When the UV absorbance increased the dosage also increased. There were, however, some notable exceptions: Round 1 Olifantsvlei water with initial $\mathrm{UV}_{254}$ absorbance of $13.1 \mathrm{~m}^{-1}$ required a lower dosage of $48 \mathrm{mg} \cdot \ell^{-1}$ and Umzoniana Round 2 with initial $\mathrm{UV}_{254}$ absorbance of $14.8 \mathrm{~m}^{-1}$ required a higher dose 


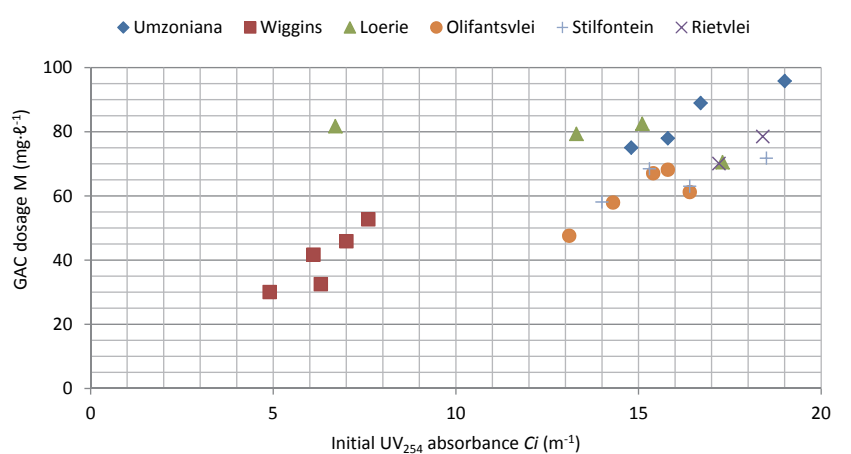

Figure 5

GAC dosage vs. initial UV ${ }_{254}$ absorbance

of $75 \mathrm{mg} \cdot \ell^{-1}$. The GAC usage of all of the samples with $R^{2}<0.90$ is not shown in Table 6.

Figure 5 presents initial $\mathrm{UV}_{254}$ absorbance versus GAC dosage. Some waters displayed a clear relationship between the activated carbon dosage and the initial $\mathrm{UV}_{254}$ absorbance. It was, therefore, possible to predict the GAC usage rate of some waters, but for others it was difficult. The data of the Plettenberg Bay water Round 2 (initial $\mathrm{UV}_{254}$ absorbance and GAC usage of $30.4 \mathrm{~m}^{-1}$ and $189.4 \mathrm{mg} \cdot \ell^{-1}$, respectively) was not included in Fig. 6 because it was out of the range of the figure.

However, it appears that the dosages required for achieving the target criterion are high compared to what can be tolerated by water treatment plants.

\section{Comparison of DOC and $\mathrm{UV}_{254}$ absorbance}

Parallel DOC analysis was performed on the Round 4 waters (i.e. Loerie, Rietvlei, Umzoniana, Olifantsvlei and Wiggins). Figure 6, representing the comparison between the DOC and $\mathrm{UV}_{254}$ absorbance data of the selected waters, showed that there was a strong linear relationship between the two surrogate parameters, for NOM characterisation.

It was also found that the GAC dosage required to remove $40 \%$ of $\mathrm{UV}_{254}$ absorbance also removed about $40 \%$ of the DOC (see Table 7). This suggests that $\mathrm{UV}_{254}$ absorbance might be used as a quick and reliable characterisation parameter for some South African waters. The specific UV absorbance (SUVA) values of the waters presented in the last column of Table 7 are good indicators of the humic acid content in water (USEPA, 1999). The SUVA values suggested that there were two categories of waters: those with a high fraction of non-humic matter (SUVA < 2) and those with a mixture of aquatic humic and non-humic matter (SUVA between 2 and 4).

\section{CONCLUSION}

The aim of the study was to investigate the removal of NOM by the use of GAC by measuring the UV absorbance at $254 \mathrm{~nm}$ $\left(\mathrm{UV}_{254}\right), 272 \mathrm{~nm}\left(\mathrm{UV}_{272}\right)$ and $300 \mathrm{~nm}\left(\mathrm{UV}_{300}\right)$, for a representative selection of South African surface waters, in batch experiments. The performance of activated carbon was considered over a range of dosages in order to detect some general patterns - not to suggest practical or economical values. The data for the three wavelengths were compared first:

- It was found that, at all three wavelengths, the percentage of NOM removal was practically the same. The differences amongst these wavelengths can, therefore, not be used to characterise the differences in NOM composition of the

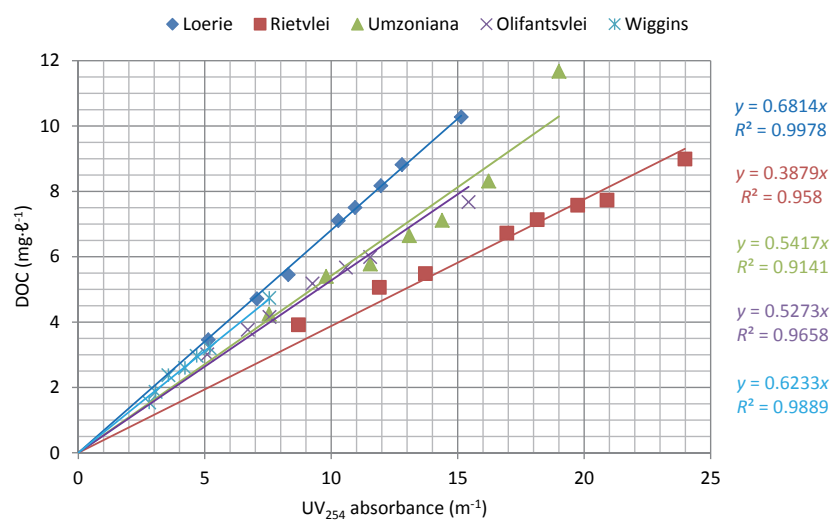

Figure 6

Relationship between DOC and UV 254 absorbance for some Round 4 waters

\begin{tabular}{|l|c|c|c|c|c|}
\hline \multicolumn{7}{|c|}{ DOC and UV ${ }_{254}$ absorbance removal } \\
\hline Plant name & $\begin{array}{c}\text { Initial } \\
\mathbf{U V}_{254} \\
\left(\mathbf{m}^{-1}\right)\end{array}$ & $\begin{array}{c}\text { Dosage } \\
\text { for 40\% } \\
\mathbf{U V}_{254} \\
\text { removal } \\
\left(\mathrm{mg} \cdot \ell^{-1}\right)\end{array}$ & $\begin{array}{c}\text { Initial } \\
\text { DOC } \\
\left(\mathrm{mg} \cdot \ell^{-1}\right)\end{array}$ & $\begin{array}{c}\text { DOC } \\
\text { removed }\end{array}$ & $\begin{array}{c}\text { SUVA } \\
(\ell \cdot \mathrm{mg} \\
\left.\mathbf{}^{-1}\right)\end{array}$ \\
\hline Wiggins & 7.6 & 53 & 4.74 & $40 \%$ & 1.60 \\
\hline Umzoniana & 19.0 & 96 & 11.68 & $50 \%$ & 1.63 \\
\hline Loerie & 15.1 & 83 & 10.28 & $39 \%$ & 1.47 \\
\hline Rietvlei & 24.0 & 94 & 8.99 & $36 \%$ & 2.67 \\
\hline Olifantsvlei & 15.4 & 67 & 7.68 & $34 \%$ & 2.01 \\
\hline
\end{tabular}

different sources. Any of the three wavelengths can be used to assess the NOM removal by GAC.

- The $U V_{272}$ and $U V_{300}$ absorbance values were, on average, 0.82 and 0.53 times the $\mathrm{UV}_{254}$ absorbance data, respectively. The $\mathrm{UV}_{254}$ absorbance data were chosen for the remainder of the analysis, as it is the most popular wavelength used in the published literature.

The Freundlich equilibrium equation provided a good mathematical description of the adsorption. The granular activated carbon dosage could be calculated for an arbitrary goal of $40 \%$ of UV absorbance removal by fitting this isotherm to the $\mathrm{UV}_{254}$ absorbance data. It was found that:

- The value of the initial UV absorbance value impacts on the dosage rate. Results suggested that when the initial UV absorbance is low, the GAC dosage required is also likely to be small.

- The GAC usage rate is not only dependent on the initial $\mathrm{UV}_{254}$ absorbance of the water but also on the composition (nature and concentration) of the NOM indicating a need for improved NOM characterisation.

Dissolved organic carbon analysis was conducted on some waters:

- Strong linear relations were found between the DOC and the $\mathrm{UV}_{254}$ absorbance values, suggesting that, for those waters, the latter could be used as a quick and reliable characterisation surrogate parameter for NOM removal.

- The dosages required to remove $40 \%$ of UV absorbance also removed approximately the same percentage of DOC. 


\section{ACKNOWLEDGMENTS}

The authors gratefully acknowledge the financial support from the University of Johannesburg and the South African Water Research Commission.

\section{REFERENCES}

BATTERMAN S, ZHANG L and WANG S (2000) Quenching of chlorination disinfection by-product formation in drinking water by hydrogen peroxide. Water Res. 34 (5) 1652-1658.

CORNELISSEN ER, MOREAU N, SIEGERS WG, ABRAHAMSE AJ, RIETVELD LC, GREFTE A, DIGNUM M, AMY G and WESSELS LP (2008) Selection of anionic exchange resins for removal of natural organic matter (NOM) fractions. Water Res. 42 (1-2) 413-423.

EDZWALD JK and TOBIASON JE (2010) Chemical principles, source water composition, and watershed protection. In: Edzwald JK (ed.) Water Quality \& Treatment - A Handbook on Drinking Water $\left(6^{\text {th }}\right.$ edn.). AWWA and McGraw-Hill, New York.

GARCÍA I (2011) Removal of natural organic matter to reduce the presence of trihalomethanes in drinking water. Doctoral thesis, School of Chemical Science and Engineering, Royal Institute of Technology, Stockholm.

HAARHOFF J, MAMBA B, KRAUSE R, VAN STADEN S, NKAMBULE T, DLAMINI S and LOBANGA KP (2013) Natural organic matter in drinking water sources: Its characterisation and treatability. WRC Report No. 1883/1/12. Water Research Commission, Pretoria.

HALLAM NB, WEST JR, FORSTER CF and SIMMS J (2001) The potential for biofilm growth in water distribution systems. Water Res. 35 (17) 4063-4071.

KARANFIL T, SCHLAUTMAN MA and ERDOGAN I (2002) Survey of DOC and UV measurement practices with implications for SUVA determination. J. AWWA 94 (12) 68-80.

KORSHIN GV, LI C-W and BENJAMIN MM (1997) The decrease of UV absorbance as an indicator of TOX formation. Water Res. 31 (4) 946-949.
KRISTIANA I, JOLL C and HEITZ A (2011) Powdered activated carbon coupled with enhanced coagulation for natural organic matter removal and disinfection by-product control: Application in a Western Australian water treatment plant. Chemosphere 82 (5) 661-667.

MATILAINEN A, VIENO N and TUHKANEN T (2006) Efficiency of the activated carbon filtration in the natural organic matter removal. Environ. Int. 32 (3) 324-331.

MELNICK RL, NYSKA A, FOSTER PM, ROYCROFT JH and KISSLING GE (2007) Toxicity and carcinogenicity of the water disinfection byproduct, dibromoacetic acid, in rats and mice. Toxicology 230 (2-3) 126-136.

OBERHOLSTER P (2010) The current status of water quality in South Africa. In: A CSIR perspective on water in South Africa - 2010. CSIR Report No. CSIR/NRE/PW/IR/2011/0012/A.

ØDEGAARD H, ØSTERHUS S, MELIN E and EIKEBROKK B (2010) NOM removal technologies - Norwegian experiences. Drink. Water Eng. Sci. 3 (1) 1-9.

RANDTKE SJ and SNOEYINK VL (1983) Evaluating GAC adsorptive capacity. Jour. AWWA 75 (8) 406-413.

SCHREIBER B, BRINKMANN T, SCHMALTZ V and WORCH E (2005) Adsorption of dissolved organic matter onto activated carbon - the influence of temperature, absorption wavelength, and molecular size. Water Res. 39 (15) 3449-3456.

SHARP EL, PARSONS SA and JEFFERSON B (2006) Seasonal variations in natural organic matter and its impact on coagulation in water treatment. Sci. Total Environ. 363 (1-3) 183-194.

USEPA (UNITED STATES ENVIRONMENTAL PROTECTION AGENCY) (1999) Enhanced Coagulation and Enhanced Precipitative Softening Guidance Manual. EPA 815-R-99-012. US EPA, Washington.

UYAK V, OZDEMIR K and TOROZ I (2008) Seasonal variations of disinfection by-product precursors profile and their removal through surface water treatment plants. Sci. Total Environ. 390 (2-3) 417-424.

VAN DER KOOIJ D (1998) Potential for biofilm development in drinking water distribution systems. J. Appl. Microbiol. 85 (S1) 39S-44S. 